\title{
ATP5F1B wt Allele
}

National Cancer Institute

\section{Source}

National Cancer Institute. ATP5F1B wt Allele. NCI Thesaurus. Code C118526.

Human ATP5F1B wild-type allele is located in the vicinity of 12p13.3 and is approximately $8 \mathrm{~kb}$ in length. This allele, which encodes ATP synthase subunit beta, mitochondrial protein, is involved in both AT P synthesis and proton transport. 